\title{
VALORIZACIJA KULTURNOG NASLEĐA ZAJEČARSKOG UPRAVNOG OKRUGA ZA POTREBE RAZVOJA TURIZMA STUDIJA SLUČAJA: FELIX ROMULIANA
}

\author{
Nataša Savić1, \\ Dušan Borovčanin², \\ Miroslav Knežević ${ }^{3}$ \\ ${ }^{1}$ Student Fakulteta za turistički i \\ hotelijerski menadžment, \\ Univerzitet Singidunum, \\ Beograd, Srbija \\ 2Univerzitet Singidunum, \\ Beograd, Srbija
}

\begin{abstract}
Rezime:
Veoma važan detalj nacionalnog identiteta predstavljaju kulturno-istorijski spomenici, koji svedoče o starosti, kulturi i nasleđu jednog naroda ili područja. Jedan deo kulturno-istorijskih spomenika čine i arheološka nalazišta, koja mogu predstavljati bitan činilac u razvoju turizma jednog područja. Veliki broj zemalja u svetu u dužem vremenskom periodu zahvaljujući promociji arheološkog turizma i razvoju destinacija ostvaruje značajne prihode na godišnjem nivou. U Srbiji je predviđeno, na osnovu izrađenog Poslovnog (master) plana, da se „Put rimskih imperatora“ pozicionira kao turing proizvod visoke vrednosti koji, na osnovu starorimskog kulturno-istorijskog nasleđa, objedinjava materijalno i nematerijalno kulturno nasleđe. U ovom radu pokušaćemo da približimo mogućnosti unapređenja i razvoja destinacije, koja predstavlja deo projekta „Put rimskih imperatora“. Felix Romuliana kao značajan deo ovog projekta predstavlja rezidenciju imperatora Gaja Valerija Galerija Maksimilijana (297-311.), mesto u kome je on rođen, sahranjen i uznesen među bogove (apoteoza). Lokalitet je sredinom 2007. godine ušao na UNESCO-vu listu svetske kulturne baštine i nalazi se u okolini mesta Gamzigrad i Gamzigradska banja, a nadomak Zaječara.
\end{abstract}

Ključne reči:

Kulturno nasleđe, kulturni turizam, Felix Romuliana, UNESCO

UVOD

Ideja o čuvanju, zaštiti i prezentaciji kulturnog nasleđa čovečanstva nije ideja koja traje vekovima. Zapravo, tek 1954. godine, Liga naroda je nakon drugog svetskog rata organizovala konvenciju o zaštiti kulturnog nasleđa u slučaju vojnih sukoba. (Gravari-Barbas et al., 2018) Ipak, nakon brojnih inicijativa, gotovo dve decenije nakon te konvencije,1972. godine organizovana je nova konvencija za zaštitu svetskog, prirodnog i kulturnog nasleđa. Broj država potpisnica rastao je postepeno od 24 države u 1976. pa sve do 193 u 2017. godini. (Gravari-Barbas et al., 2018) Republika Srbija, ratifikovala je sporazum sa konvencije 2001. godine. (United Nations Educational, Scientific and Cultural Organization, 2018) Od tada do danas, iz Republike Srbije, na različite UNESCO liste iz Srbije je upisano ukupno 22 prirodna i kulturna dobra. (United Nations Educational, Scientific and Cultural
Correspondence:

Nataša Savić

e-mail:

natasa.savic.171@singimail.rs 
Organization, 2018) Struktura nasleđa upisanog prema listama iz Srbije je sledeća: UNESCO tentativna lista (12), lista svetskog kulturnog nasleđa (5), lista nematerijalnog kulturnog nasleđa (2), UNESCO lista „Čovek i biosfera“ (2) i u okviru UNESCO programa „Pamćenje sveta“ (2).

Kako su godine prolazile broj lista ali i spisak dobara upisanih na različite liste je konstanto u porastu. Uz izuzetno dinamičan razvoj domaćeg i međunarodnog turizma, kao i sve veće učešće kulturnih motiva prilikom uključivanja u turistička putovanja, svetsko kulturno nasleđe pojavilo se kao značajan „magnet“ za privlačenje velikog broja posetilaca. To je na određenim destinacijama dovelo i do pojave i rasta različitih pokreta anti-turizma, dominantno zbog ugrožavanja statusa određenog kulturnog nasleđa, negativnom uticaju turista na kvalitet života lokalnog stanovništva, održivosti životne sredine pod pritiskom turista kao i ograničenim ekonomskim doprinosima. (Seraphina et al., 2018)

Iako turizam u Srbiji beleži konstante stope rasta turističkog prometa, mesta upisana na UNESCO listu ne prednjače na listi broja posetilaca. (Ministarstvo trgovine, turizma i telekomunikacija, 2018) Razlozi za to su višestruki i sveobuhvatna analiza tih faktora prevazilazi okvire ovog rada. Upravo iz tog razloga, u ovom radu pažnja je usmerena na arheološki lokalitet Felix Romuliana koji je jedan od 5 elemenata nasleđa R. Srbije upisanih na UNESCO listu. U nastavku rada, analiziran je turistički promet od 2001-2017. godine na arheološkom nalazištu iz rimskog perioda Felix Romuliana.

\section{FELIX ROMULIANA: NASLEĐE VISOKE VREDNOSTI}

Feliks Romuliana je monumentalna carska palata i rezidencija imperatora Gaja Valerija Galerija Maksimilijana (Gaius Valerius Maximianus Galerius; 293-311), koji je pred kraj svoje vladavine odlučio da se povuče u rodni kraj. (Turistička organizacija Srbije, 2018) Imperator je palatu posvetio svojoj majci Romuli i nazvao je po njoj, što je potvrđeno u različitim spisima iz IV i VI veka, a otkriveno tek 1984. godine. (Felix Romuliana, 2018) I car Galerije i njegova majka Romula sahranjeni su u blizini palate na lokalitetu "Magura" - poslednje mesto na kome je u Rimskom carstvu izveden čin apoteoze i gde su otkrivene dve zidane grobnice. Inače, Galerije je jedan od sedamnaestorice imperatora Rimskog carstva rođenih na tlu današnje Srbije. Zanimljivo je i to da je on prvi rimski car koji je doneo Edikt o toleranciji (30. aprila 311. u Nikomediji), kojim je hrišćanima prvi put $\mathrm{u}$ istoriji priznata sloboda veroispovesti. (Ekonomski fakultet, 2018) Dve godine nakon toga Konstantin donosi Milanski edikt. Palata Feliks Romuliana nikada nije dovršena, a u IV veku ovaj impozantni posed prisvaja hrišćanska crkva. Tokom V veka palatu su razarali varvari, a u VI veku Justinijan I obnovio je Romulijanu i pretvorio je u pograničnu tvrđavu. Od kraja VI veka, palatu i taj kraj naseljavaju Sloveni i koriste je do XI veka. (Ekonomski fakultet, 2018) U XIX veku, nemački baron Fon Herder je obilazio Srbiju tražeći rudnike i tada otkrio carsku palatu. Kasnije je Feliks Kanic, austrougarski putopisac i arheolog, procenio da je u pitanju Kastrum, rimsko vojno utvrđenje (mnogi stariji građani u Zaječaru i okolini i danas ovaj lokalitet nazivaju Kastrum, prim.aut.). Jugoslovenski arheolozi su 1953. godine pokrenuli istraživanja i nakon mesec dana iskopavanja otkriveni su mozaici koji su ukazivali da ovo nije vojno utvrđenje, već nešto mnogo značajnije. Da je u pitanju carska palata, otkrio je arheolog dr Dragoslav Srejović 1984. godine, pronašavši fragment arhivolte (polukružni luk koji spaja dva stuba), na kojem se nalazio natpis FELIX ROMULIANA. (Fondacija Srpski Legat, 2018) Unutar kompleksa nalazili su se raskošna carska palata, mali hram, veliki hram, terme, horeum, tri hrišćanske crkve i druge građevine. Podni mozaici spadaju u najbolja građevinska ostvarenja kasnoantičkog doba na tlu Evrope. Prema tvrdnji arheologa Feliks Romuliana se može porediti sa Dioklecijanovom palatom u Splitu (Hrvatska), po svom značaju, ali je i daleko bogatije arheološko nalazište. Uz detaljnu analizu rezultata turističkog prometa samog nalazišta, upoređeni su rezultati sa rezultatima Grada Zaječara, kao i rezultatima njihovih propagandnih aktivnosti putem interneta. U delu zaključaka, sublimirana su zapažanja i date preporuke za uspešniju valorizaciju arheološkog nalazišta.

\section{ANALIZA TURISTIČKOG PROMETA NA LOKALITETU FELIX ROMULIANA OD 2001-2017. GODINE}

Arheološki lokalitet Feliks Romuliana u nadležnosti je Narodnog muzeja Zaječar koji i vodi evidenciju turističkog prometa samog lokaliteta Felix Romuliana.. Podaci za ovo istraživanje dobijeni su zahvaljujući saradnji sa arhivom i menadžmentom same ustanove. $U$ radu su pored podataka o turističkom prometu samog lokaliteta 
korišćeni i podaci o turističkom prometu grada Zaječara i Gamzigradske banje kao i drugi kvalitativni podaci poput intervjua i izjava menadžmenta lokalne turističke organizacije i Narodnog muzeja grada Zaječara.

Na grafikonu broj 1. prikazan je turistički promet za lokalitet Felix Romuliana u periodu od 2001-2017. godine po kategorijama: grupne posete, individualne posete, posete stranaca, ostala dešavanja i zbirno dat turistički promet, uključujući sve kategorije. ${ }^{1}$ Način klasifikacije turista rešenje je menadžmenta Narodnog muzeja grada Zaječar. Metodologija evidencije se tokom proteklih 18 godina menjala u manjoj meri, što će tokom rada biti i prikazano.

Grafikon 1. Turistički promet na lokalitetu Felix Romuliana u periodu 2001-2017. godine

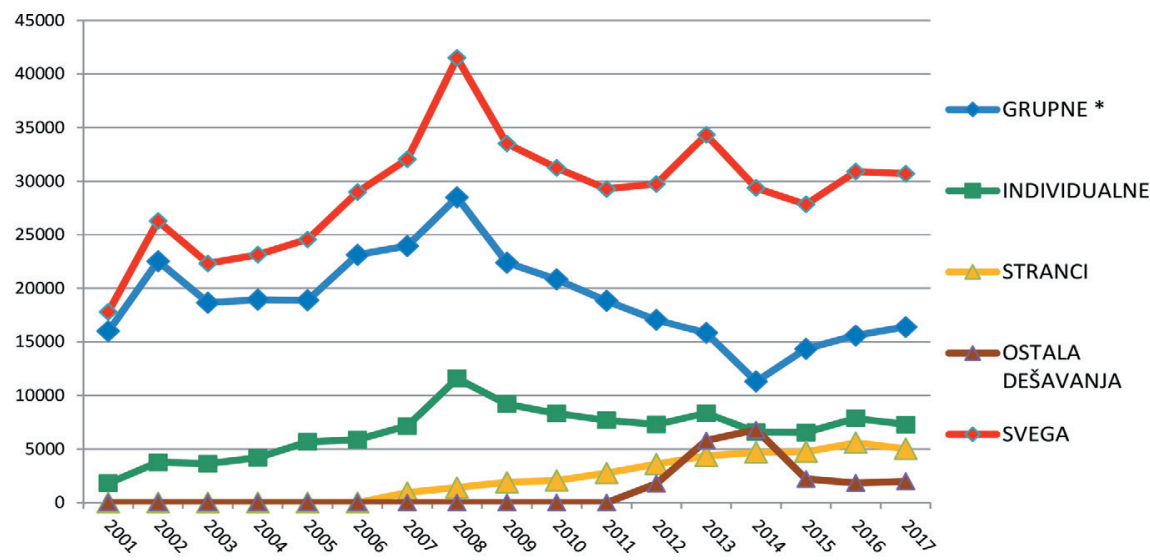

Izvor: Narodni muzej Zaječar

Na grafikonu broj 1. jasno je uočljiv značaj grupnih posetilaca u ukupnom broju posetilaca, dok je uticaj ostale tri kategorije primetan tek u pojedinim godinama. Na bazi ovog grafika, teško je izneti jasna tumačenja. Iz tog razloga na grafikonima 2 i 3 jasno su razgraničene individualne posete i posete inostranih posetilaca (grafikon 2), dok su na grafiku broj 3 prikazane ukupno grupne posete i posete na bazi ostalih dešavanja.

Grafikon 2. Uporedni prikaz individualnih i stranih posetilaca lokalieteta Felix Romulijana 2001-2017.godina

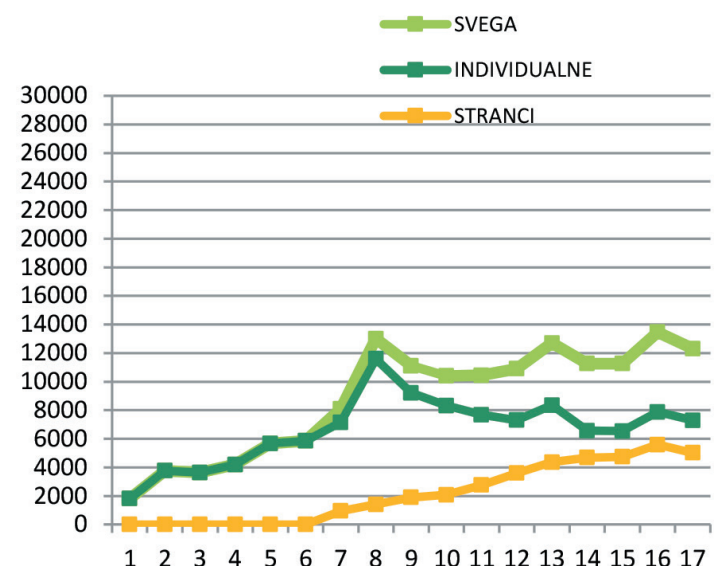

Izvor: Narodni muzej Zaječar
Grafikon 3. Uporedni prikza grupnih poseta i poseta na bazi ostalih dešavanja na lokalitetu Felix Romulijana 2001-2017. godina

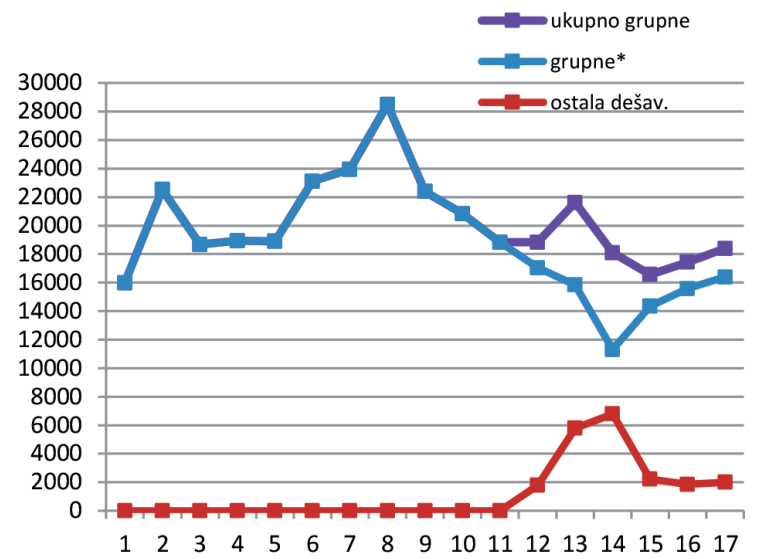

Izvor: Narodni muzej Zaječar

1 Za analizu potrebno je naglasiti sledeće važne činjenice:

- „Grupne posete“ predstavljaju dolazak grupa koje imaju 20 ili više članova*

- „Individualne posete“ su do 2007.godine beležene zbirno, u smislu domaćih i stranih posetilaca

- „Ostala dešavanja“ predstavljaju dolazak organizovanih grupa (neplaćene posete) u toku značajnih dešavanja u gradu Zaječaru, kao što su „Gitarijada“, „Dani Zorana Radmilovića“, itd. i beleže se tek od 2012. godine. 
Na grafikonima 2. i 3. može se videti porast broja individualnih i grupnih posetilaca. S obzirom da je do 2006.godine beležena zbirno poseta domaćih i stranih pojedinačnih posetilaca, na grafikonu broj 2. je data i zbirna poseta individualnih posetilaca. Tako da se može uočiti prilično ujednačen porast, sa pikovima u određenim godinama. Takođe je data i zbirna poseta grupnih posetilaca, na grafikonu broj 3 jer je odvojeno beleženje grupa koje se vezuju uz specijalna dešavanja Zaječaru ili Gamzigradu počelo tek 2012. godine što je već i naglašeno. Godina 2008. evidentno ima značajan porast posetilaca u svim kategorijama, što može biti i očekivano nakon upisa lokaliteta na UNESCO listu (2007.g.). Ovim je još jednom potvrđen značajan pozitivan efekat na turističke tokove određenog lokaliteta od trenutka njegovog upisivanja na UNESCO listu. (Cravidão et al.,2018)

Takođe je uočljivo i pozitivno istupanje i 2013.godine u odnosu na prosečan godišnji broj posetilaca. Budući da 2013. godina u međunarodnom ali i domaćem turizmu nije obeležena kao godina koja je imala posebno drugačiju dinamiku, obavljen je i razgovor sa vodičem Narodnog muzeja Zaječar, gospođom Adrijanom Maksimović. Razlog za ovako drugačiji rezultat u 2013. godini, prema rečima gospođe Maksimović, leži u činjenici da je uoči 2013. godine bila pojačana promotivna aktivnost, posebno u domenu elektronskog oglašavanja, koja je dala pozitivne rezultate na turistički promet. Promotivni napori bili su usmereni prema ustanovama za obrazovanje dece i adolescenata, tačnije osnovnim i srednjim školama čije učešće u ukupnim posetama i zauzima značajano mesto, što će biti kasnije i pokazano. Pored promotivnih napora, primenjena je i drugačija cenovna politika koja se odnosila na ovaj ciljni tržišni segment, na način da je određena kombinovana cena ulaznice koja podrazumeva obilazak tri objekta bude po ceni samo jedne. Ipak, nije objašnjen razlog zbog kojeg sa tim aktivnostima, u godinama koje su usledile, nije nastavljen.

Na osnovu grafikona 2 i 3 može se uočiti i drastično veći broj posetilaca koji dolazi od grupnih poseta, 2008.g. ukupan broj individualnih posetilaca bio je 13.005, a ukupan broj iz grupnih poseta 28.497. Posmatranje podataka na mesečnom nivou je takođe veoma značajno za analizu ukupne posete i razumevanje zakonitosti raspodele na godišnjem nivou. Grafikon broj 4. pokazuje kretanje grupnog turističkog prometa tj. grupne posete turista lokalitetu u 2016. godini tokom 12 meseci. Očigledno je da tokom maja i oktobra, kada se inače sprovode ekskurzije školske dece, broj grupa i samim tim i ukupan broj posetilaca znatno raste u odnosu na ostale mesece u godini. Ovo je potvrđeno i od strane g-đe. Adrijane Maksimović koja je istakla da posete đačkih i studentskih ekskurzija čine najznačajniji udeo u grupnim posetama.

Grafikon 4. Grupne posete lokalitetu Felix Romulijana u 2016. godini

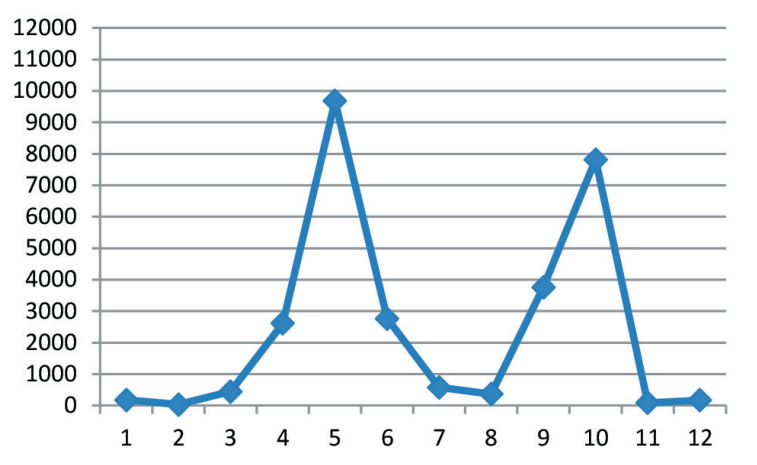

Izvor: Narodni muzej Zaječar
Grafikon 5. Individualne posete lokalitetu Felix Romulijana u 2016. godini

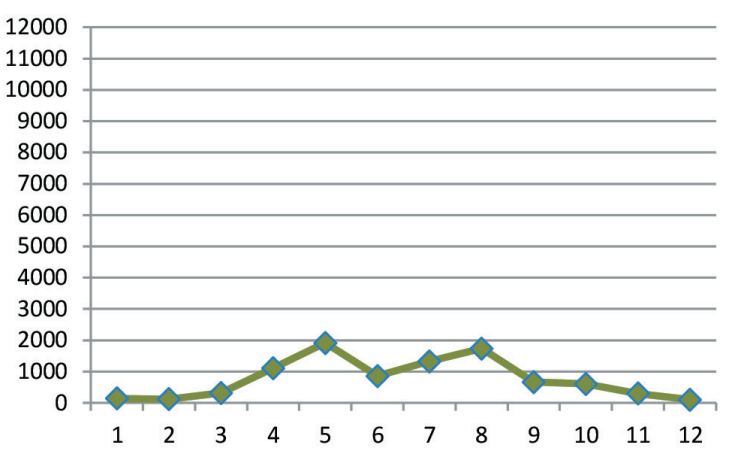

Izvor: Narodni muzej Zaječar

$\mathrm{Na}$ osnovu mesečne raspodele tokom poslednjih 18 godina, uočeno je da je raspodela gotovo identična. Iz tog razloga, ali i iz tehničkih ograničenja koje ovaj rad podrazumeva, u nastavku će biti prikazana samo 2016. godina. Grafikon broj 5. pokazuje kretanje individualnog turističkog prometa tj. individualne posete turista lokalitetu u 2016. godini tokom 12 meseci. Priličan rast broja posetilaca je očigledan u maju i avgustu, a prema rečima g-đe. Adrijane Maksimović on je posledica godišnjih odmora i specijalnih događaja u gradu Zaječaru i okolini. Zahvaljujući obaveštenjima koje postavljaju sajtovi www.srbija.travel i www.zajecar.info može se uočiti da se većina događaja u Zaječaru i Gamzigradskoj banji odvija tokom avgusta (Likovna kolonija „Gamzigrad“, 
Kamp klasične muzike, Međunarodna filozofska škola „Felix Romuliana“, Gitarijada, Antika fest) i maja meseca (Pozorišni festival za decu, Sabor narodnog besedništva - „Dani Adama Bogosavljevića“, Smotra narodnog stvaralaštva „Potekla voda studena“, Festival mladih pesnika „Dani poezije“). Jedini događaj van ovih meseci su „Dani Zorana Radmilovića“ i oni se dešavaju u oktobru, što prema rečima zaposlenih u Muzeju Zaječar, doprinosi neznatno grupnoj posećenosti u oktobru. (Turistička organizacija Srbije, 2018) (Grad Zaječar, 2018)

Daljnjom analizom došli smo i do strukture stranih posetilaca koja je vrlo značajna za ocenu potencijala i valorizacije lokaliteta na međunarodnom nivou. Analiza pokazuje da je poseta stranih turista iz godine u godinu sve veća, kako u gradu Zaječaru i Gamzigradskoj banji, tako i na lokalitetu Felix Romuliana. I za ovo posmatranje i analizu uzeli smo 2016.godinu, jer je broj stranih posetilaca bio najveći od kada se odvojeno beleže njihove posete i iznosio je 5.587. Od 2013.godine, od kada se beleže strani turisti prema zemlji iz koje dolaze, daleko je najveći broj posetilaca iz Bugarske (u 2016.g. 36\% od ukupnog broja stranaca). Tokom svih godina, od 2013. do 2017.g. značajan procenat dolazaka ostvaruju turisti iz Slovenije, Rumunije, Nemačke, Poljske, Italije i Francuske (u 2016.g. čine zbirno 38\% od ukupnog broja stranaca).

Grafikon 6. Struktura inostranih posetilaca lokalitetu Felix Romuliana u 2016. godini

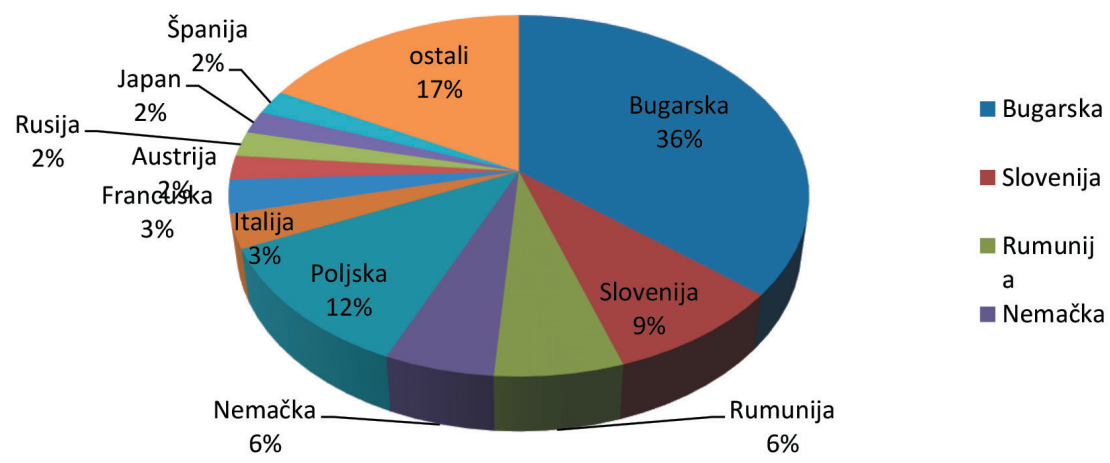

Izvor: Narodni muzej Zaječar

Zahvaljujući podacima dobijenim iz Ministarstva trgovine, turizma i telekomunikacija i iz Turističke organizacije Srbije može se uraditi uporedan prikaz i analiza broja turista u Zaječaru i Gamzigradskoj banji i broja posetilaca lokalitetu Feliks Romuliana. Na grafikonu broj 7 vidi se uporedan prikaz sa odvojenim domaćim i inostranim turistima u Zaječaru i gamzigradskoj banji i posetiocima lokalitetu. Posmatramo za trenutak samo 2017.godinu. u kojoj je broj domaćih turista u Zaječaru i gamzigradskoj banji iznosio 9.502 i broj inostranih 5.709. Zbirno domaći i strani turisti ostvarili su 15.292 turista, dok je broj posetilaca lokalitetu Felix Romuliana iste godine bio 30.701. Očigledno je da broj posetilaca lokalitetu Feliks Romuliana premašuje broj turista u gradu Zaječaru i Gamzigradskoj banji za više od 100\%.

Ipak, ne treba ispustiti iz vida da se radi o različitim kategorijama, te da su podaci o turističkom prometu za Grad Zaječar i Gamzigradsku banju prikazali isključivo posetioce koji su ostvarili noćenje uz prijavu u određenom kategorisanom smeštajnom objektu, dok se na primeru lokaliteta Felix Romuliana radi o jednodnevnim posetiocima koji su izvršili obilazak samog lokaliteta. Iz tog razloga ovi podaci nisu u potpunosti uporedivi, ali svakako daje njihov odnos trenutno opravdaniji, nego da je situacija obrnuta u korist grada Zaječara i Gamzigradske banje, budući da lokalitet Felix Romuliana predstavlja jedan od najznačajnijih vidova ponude ovog okruga. Ipak, turistički poslenici u gradu Zaječaru i Gamzigradskoj banji, trebalo bi da ulože dodatne napore u osmišljavanju kvalitetnih vidova ponude, kako bi se deo posetilaca sa lokaliteta Felix Romuliana zadržavao i ostvarivao noćenje i samim tim i dodatne prihode u Gradu Zaječaru ili Gamzigradskoj banji. 
Grafikon 7. Uporedan prikaz broja turista u Zaječaru i Gamzigradskoj banji i

lokalitetu Felix Romuliana 2014-2017. godine

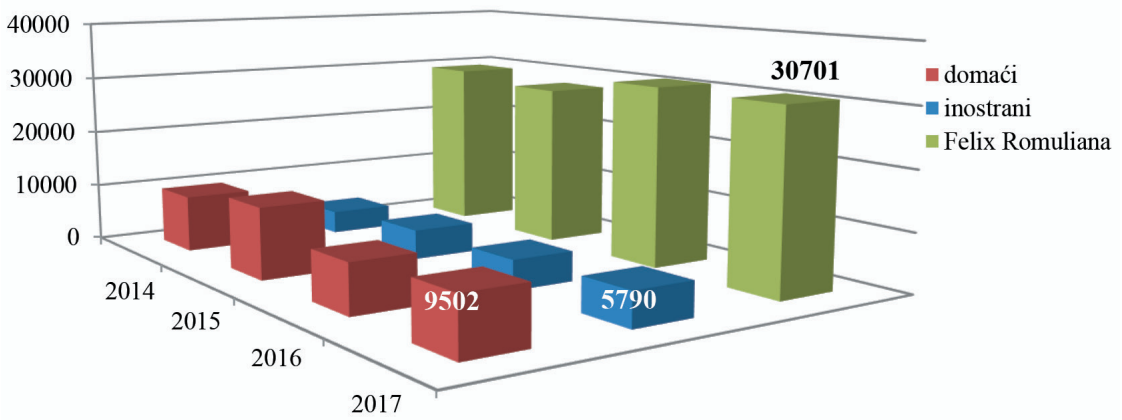

Izvor: Narodni muzej Zaječar

Ukoliko se posmatra broj noćenja u gradu Zaječaru i Gamzigradskoj banji, može se jasno uočiti pad broja noćenja domaćih turista u 2016. i 2017. godini u odnosu na prethodne godine. Broj noćenja domaćih turista je iz 2015.g. opao u 2016. za 26,4\%, odnosno za 15,7\% u 2017.g. (grafikon broj 8) Primetno je da broj noćenja inostranih turista ima lagan kontinualan porast. Ovaj podatak treba da izazove posebnu pažnju, budući da se radi o suprotnom trendu kada je u pitanju turistički promet domaćih turista u istom periodu, kao i da je Ministarstvo trgovine, turizma i telekomunikacija baš u ovom periodu krenulo sa stimulacijom domaćeg turizma putem turističkih vaučera. (Ministarstvo trgovine, turizma i telekomunikacija, 2018)

Grafikon 8. Broj noćenja u Zaječaru i Gamzigradskoj banji 2014-2017. godina (zbirni prikaz)

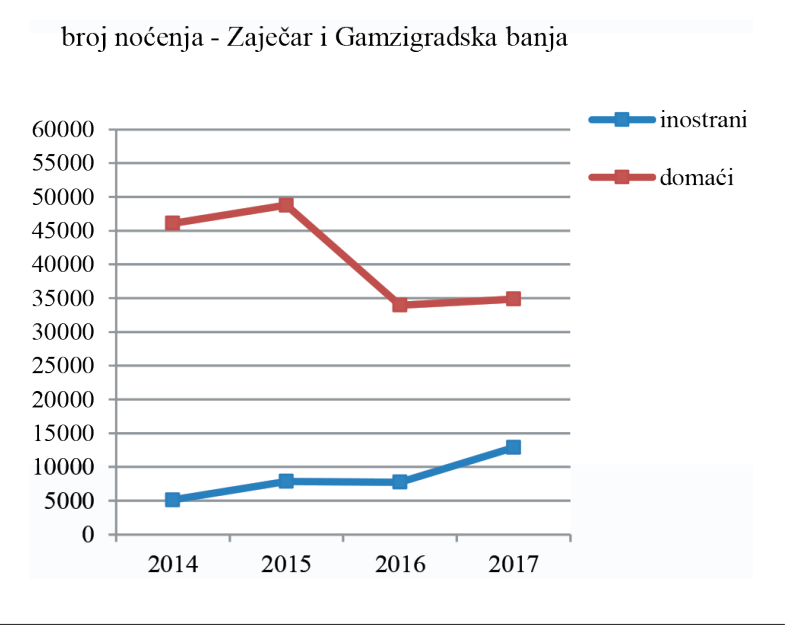

Izvor: Turistička organizacija Grada Zaječara
Grafikon 9. Sturktura smeštajnih kapaciteta grada Zaječara i Gamzigradske banje

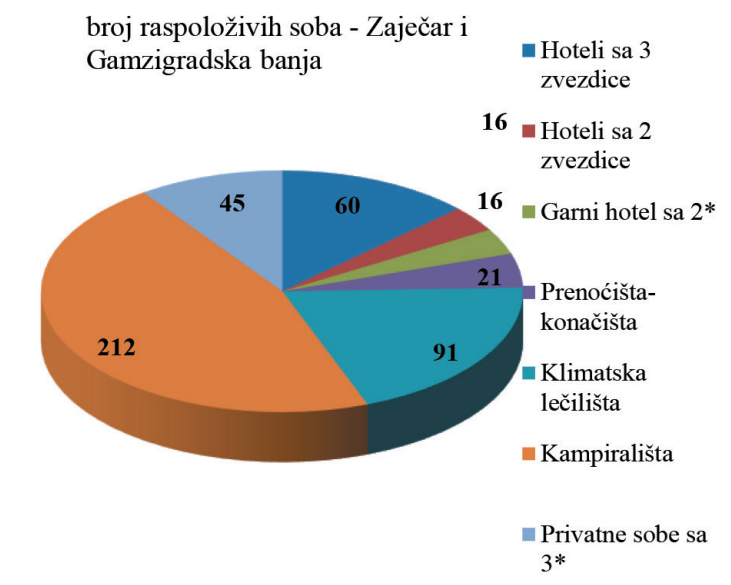

Izvor: Turistička organizacija Grada Zaječara

Evidentno je kada se pogledaju rezultati turističkog prometa za lokalitet Felix Romulijanu, ali i za Grad Zaječar i Gamzigradsku banju da ne možemo govoriti o međunarodno razvijenim turističkim destinacijama. Iako je sam lokalitet prema master planu prepoznat kao proizvod visoke vrednosti, udeo inostranih posetilaca tokom godina ostaje na značajnom niskom nivou, dok i godišnji promet domaćih posetilaca ne beleži značajne rezultate u odnosu na druga turistička mesta u našoj zemlji. Kako bismo dodatno utvrdili uzroke za ovako nizak stepen turističkog razvoja, analizirali smo smeštajne kapacitete grada Zaječara kao i rezultate istraživanja Turističke organizacije Srbije (TOS) o stavovima stranih turista u Srbiji iz 2016. godine.

Podaci o broju smeštajnih kapaciteta, prikazani na grafikonu broj 9 prikazuju nerazvijenu mrežu smeštajnih kapaciteta nedovoljnog nivoa kvaliteta koja funkcioniše sa niskom stopom popunjenosti (11\% u 2017. godini). ${ }^{2}$

2 Podaci dobijeni od strane Turističke organizacije Srbije, budući da Republički zavod za statistiku i saopštenja Ministarstva trgovine turizma i telekomunikacija u svojim redovnim objavama ne ističu ove podatke. 
Uz to, sam lokalitet Felix Romuliana ne poseduje svoju internet prezentaciju kako web site, tako ni stranicu na društvenim medijima. Ovo je posebno značajno imajući u vidu rezultate istraživanja TOS o stavovima i ponašanjima stranih turista. Turistička organizacija Srbije uradila je u toku 2016.godine istraživanje „Stavovi i ponašanje stranih turista u Srbiji 2016". (Turistička organizacija Srbije, 2018) Ispitivanje je rađeno putem ankete i to na 28 lokacija širom Srbije. Istine radi, istraživanje nije obuhvatilo strane posetioce iz zaječarskog okruga, ali je najveće i metodološki najsveobuhvatnije istraživanje tok karaktera. Od značaja za ovaj rad jeste da su kao izvore informisanja strani turisti na prvom mestu naveli internet sajtove, sa 63,9\%. S obzirom da su Internet sajtovi najzastupljeniji u odgovorima, naglašavamo da je na pitanje o najčešće korišćenim internet sajtovima (moguće je više odgovora) odgovoreno: sajtovi ugostiteljskih i ostalih objekata za smeštaj $42,8 \%$, sajtovi koji nisu specijalizovani za turizam $37,1 \%$, sajtovi koji su specijalizovani za turizam $34,2 \%$, društvene mreže 20,4\%, sajtovi TOS-a i lokalnih turističkih destinacija 17\%. Najčešće korišćeni sajtovi u kategoriji društvenih mreža bili su: Facebook 78,7\%, Instagram 12,7\%, Google 4,1\%. Konačno, kada je u pitanju ponašanje turista na destinaciji od sadržaja koje su koristili tokom posete, kulturno istorijski spomenici zauzeli su prvo mesto sa $74,4 \%$, zatim slede izleti u prirodi sa $39,3 \%$, poseta manifestaciji ili događaju sa $30,1 \%$, sportsko rekreativni sadržaji sa $19,4 \%$ i wellness\&spa $14,2 \%$.

Imajući u vidu sve gore navedene podatke i rezultate u zaključku će biti izneta sumirana zapažanja i preporuke za dalji razvoj.

\section{ZAKLJUČAK}

Kulturno istorijsko nasleđe sa kojim Srbija raspolaže predstavlja prednost Srbije u SWOT analizi važeće strategije za razvoj turizma Srbije (Vlada Republike Srbije, 2018). Ipak, neki od najvažnijih i najvrednijih spomenika i lokaliteta sa bogatim kulturnim nasleđem ne prednjače u rezultatima turističkog prometa u odnosu na druge destinacije, naprotiv. U ovom radu, urađena je analiza turističkog prometa lokaliteta Felix Romuliana, kao i analiza turističke ponude Grada Zaječara i Gamzigradske banje. Urađena je uporedna analiza njihovih rezultata, sagledane su promotivne aktivnosti koje ustanove iz nadležnosti ulažu i na bazi svega sagledanog došlo se do nekoliko zaključaka koje ćemo predstaviti u nastavku.

- Lokalitet Felix Romulijana još uvek ne predstavlja međunarodno razvijen turistički proizvod u odnosu na ostale destinacije u Srbiji imajući u vidu broj i udeo stranih posetilaca u poslednjih 18 godina

- Ukupan broj posetilaca značajno zavisi od učešća grupnih poseta

- Grupne posete direktno su zavisne od perioda đačkih ekskurzija

- Lokalitet Felix Romulijana ne poseduje svoju internet prezentaciju, kako u vidu veb sajta, tako ni u vidu stranice na društvenim medijima

- Struktura smeštaja u gradu Zaječaru i okolini nije odgovarajućeg kvaliteta i radi sa jako niskim procentom zauzeća kapaciteta

- Promotivni napori na prezentaciji samog lokaliteta iako su dali rezultate nisu organizovani i ne sprovode se na redovnom nivou

- Inostrani posetioci beleže blag ali kontinuiran rast u poslednjih 10 godina

$\mathrm{Na}$ bazi sagledanih rezultata kao i pregleda odgovarajuće literature ostaje da se daju preporuke za dalju stimulaciju dolazaka kako domaćih tako i inostranih posetilaca. Možda najvažniji nalaz iz studije jeste da se informacije o lokalitetu mogu pronaći samo na internet prezentaciji Turističke organizacije Srbije, Wikipediji i drugim internet prezentacijama ne relevantnih izvora. To ukazuje na ograničenu mogućnost informisanja kako domaćih tako i inostranih posetilaca. Ovo je posebno važno imajući u vidu rezultate studije obavljene od strane TOS-a koji su prezentovani u studiji. Stoga, mišljenja smo da je značajnije prisustvo na internetu sa sadržajima na drugim stranim jezicima, posebno iz onih zemalja koje već čine značajan udeo u posetiocima, nužno. Podvlačimo da je neophodno prisustvo i izrada sadržaja kako putem veb sajta tako i internet stranica najpopularnijih društvenih medija.

Zatim, prema rezultatima turističkog prometa, promotivni napori usmereni na osnovne i srednje škole uz odgovarajuću cenovnu politiku dali su rekordne rezultate. Mišljenja smo da takav pristup treba intenzivirati, 
na smišljen i koordinisan način uz kombinaciju promotivnih kanala komunikacije. Konačno, bolje povezivanje sa lokalnim manifestacijama i lokalnim stanovništvom trebalo bi da doprinese i značajnijem efektu na turistički promet samog lokaliteta.

Konačno, možda najslikovitiji način za unapređenja menadžmenta nad kulturnim nasleđem uz pomoć informacionih tehnologija dao je prof. Cantoni. (Cantoni, 2018) Njegovo mišljenje je da tehnologija pruža mogućnost unapređenja turističkih rezultata na mestima kulturno istorijskog nasleđa u čak 5 različitih aspekata: 1) Bolja prezentacija (pored interneta, razni vidovi multimedijalne prezentacije poput kratkih filmova za različite tržišne segmente; 2) Bolje iskustvo (kada posetioci već dođu na lokalitet postoje brojni načini za lakšu vizuelizaciju tog vremena poput holograma ili mobilnih aplikacija koje bi stvorile dugotrajniju sliku u pamćenju turista) Istine radi, treba naglasiti da lokalitet poseduje razvijenu android aplikaciju „Predstavite se rimskom caru Galeriju kako običaji nalažu“, čije upotreba prema rečima rukovodstva iz muzeja nije zaživela. Ograničenja postoje, budući da je razvijana samo za android uređaje, ali i da je razvijana kao deo projekta „Rimski imperatori i dunavska vinska ruta" u kojem nije učestvovao Narodni muzej grada Zaječara, te da upravljanje i dalji razvoj aplikacije takođe nije ostao u nadležnosti muzeja (The Roman Emperors and Danube Wine Route, 2018) (About Roman footprints, 2018); 3) Bolje povezivanje (turista i lokalnog stanovništva sa nasleđem, razvoj kviz aplikacija o upoznavanju lokaliteta, kreiranje različitih narativa za prezentaciju nasleđa za drugačije kulture itd.); 4) Bolje posredovanje (umrežavanje svih elemenata ponude u okrugu kroz prezentaciju samog lokaliteta) i 5) Bolje obrazovanje (razvoj online kurseva za usavršavanje kadrova koji bi radili na prezentaciji lokaliteta zbog visoke stope fluktuacije radne snage itd.)

$\mathrm{Na} \mathrm{kraju,} \mathrm{treba} \mathrm{se} \mathrm{još} \mathrm{jednom} \mathrm{osvrnuti} \mathrm{na} \mathrm{činjenicu} \mathrm{da} \mathrm{je} \mathrm{lokalitet} \mathrm{u} \mathrm{nadležnosti} \mathrm{Narodnog} \mathrm{Muzeja} \mathrm{grada}$ Zaječar što potencijalno prouzrokuje poteškoće menadžmentu za upravljanje sa dva tako složena i vredna kompleksa. Takođe, činjenica je i da jedan deo nedostataka koji je potrebno poboljšati, posebno se misli na kvalitet smeštajnih kapaciteta ali i druge sadržaje na samoj destinaciji prevazilaze okvir delovanja Narodnog muzeja te stoga treba imati razumevanja za rezultate koji se postižu. Mišljenja smo da nalazi ove studije, kao i preporuke koje su iznete u zaključnim razmatranjima mogu dati i praktične implikacije za unapređenju rezultata turističkog prometa lokaliteta Felix Romuliana kao i celog zaječarskog okruga.

\section{LITERATURA}

About Roman footprints. (2018). Preuzeto 17. avgusta sa Roman footprints: http://romanemperorsroute.org/ about/

Cantoni, L. (2018). eTourism for Heritage; Heritage and Sustainable Tourism. The Role and Challenge of Information and Communication Technologies. In S. De Acaniis, M. Gravari-Barbas, \& L. Cantoni, Tourism Management at World Heritage Sites (pp. 67-73). Lugano: Universita della Svizzera italiana.

Cravidão, F., Nossa, P., Santos, N., Dolors Vidal Casellas, M., Crous Costa , N., Aulet, S., \& Dallari, F. (2018). Tourism at World Heritage Sites, Opportunities and Challenges. In S. De Ascaniis, M. Gravari-Barbas, \& L. Cantoni, Tourism Management at UNESCO World Heritage Sites (pp. 23-31). Lugano: Universita della Svizzera italiana.

Ekonomski fakultet. (2018). Master plan kulturnoistorijske rute: Putevima rimskih careva. Beograd, Srbija.

Felix Romuliana. (2018). Preuzeto 12. avgusta sa Sokobanja: http://www.sokobanja.com/felix-romuliana

Fondacija Srpski Legat. (2018). Preuzeto 22. avgusta sa http://www.srpskilegat.rs/feliks-romulijana/

Grad Zaječar. (2018). Preuzeto 15. avgusta sa Grad Zaječar: http://www.zajecar.info/vodic/godisnje-manifestacije

Gravari-Barbas, M., Cominelli, F., Condevaux, A., Jacquot, S., \& Conti, A. (2018). UNESCO and the Convention Concerning the Protection of the World Cultural and Natural Heritage. In S. De Ascaniis, M. GravariBarbas, \& L. Cantoni, Tourism Management at UNESCO World Heritage Sites (pp. 7-15). Lugano: Università della Svizzera italiana.

Maksin-Mićić, M. (2012). Turizam i prostor. Beograd: Univerzitet Singidunum.

Ministarstvo trgovine, turizma i telekomunikacija. (2018). Preuzeto 25 aprila sa Ministarstvo trgovine, turizma i telekomunikacija: http://mtt.gov.rs/sektori/sektor-za-turizam/korisne-informacije-turisticki-prometsrbija-kategorizacija/ 
Seraphina, H., Sheeranb, P., \& Pilato, M. (2018). Over-tourism and the fall of Venice as a destination. Journal of Destination Marketing \& Management, 9, 374-376. DOI:10.1016/j.jdmm.2018.01.011

The Roman Emperors and Danube Wine Route. (2018). Preuzeto 10. avgusta sa Danube competence center: $\mathrm{http} / / /$ danubecc.org/dcc-projects/the-roman-emperors-and-danube-wine-route/

Turistička organizacija Srbije. (2018). Preuzeto 24. avgusta sa Turistička organizacija Srbije: http://www.srbija. travel/Gamzigrad.a-143.199.html

United Nations Educational, Scientific and Cultural Organization. (2018). Preuzeto 31. avgusta sa UNESCO: https://whc.unesco.org/en/statesparties/

Vlada Republike Srbije (2018). Strategija razvoja turizma Republike Srbije za period 2016-2025. Preuzeto18. avgusta sa http://mtt.gov.rs/dokumenti

\title{
VALORIZATION OF THE CULTURAL HERITAGE FOR THE PURPOSE OF TOURISM DEVELOPMENT IN THE ZAJECAR ADMINISTRATIVE AREA \\ CASE STUDY: FELIX ROMULIANA
}

\begin{abstract}
:
Cultural and historical monuments represent a very important part of a national identity, that witness history, culture and heritage of a nation. A remarkable representative of cultural and historical monuments are archaeological sites, that can play an important role for tourism development of a specific area. Numerous countries report a significant increase in revenue due to the development of archeological tourism. In Serbia, Business Master plan predicts that "The Road of the Roman Emperors" could be the touristic product of high value, which unifies tangible and intangible cultural heritage. In this paper, we will try to bring closer the possibilities of destination development, which is enlisted on the map of "The Road of Roman Emperors". Archeological site, Felix Romouliana, as a significant part of this project represents a residential palace of Roman Emperor Galerius (297-311). It is a place where he was born, berried and taken among gods. Locality is enlisted as UNESCO World Heritage site, and lies in the surroundings of the city of Gamzigrad and Gamzigrad Spa as well as the town of Zaječar in eastern Serbia.
\end{abstract}

Keywords:

Cultural heritage, Cultural tourism, Felix Romuliana, UNESCO 